\title{
Analisis Produktivitas Perbankan Syariah di Indonesia dalam Mengelola Dana Sosial
}

\author{
Ramadhan Rizky Putra, Sekarsukma Syifadhiya, \\ Sekar Aji Widyastiti, Zulfikar Bagus Pambuko* \\ Universitas Muhammadiyah Magelang \\ Email: ramadhanrp.xma@gmail.com, sekarsyifaa05@gmail.com, \\ sekarajiwidyastiti@gmail.com, zulfikar.bp@ummgl.ac.id*
}

\begin{abstract}
Under the Law Number 21 of 2008 article 4 explains the obligation for Islamic banks in Indonesia to manage social funds, besides the funding and financing activities. This study aims to analyse the level of productivity of social funds at Islamic banks. Data analysis using Malmquist Productivity Index (MPI) technique on 8 BUS in 2013-2017. The input variables are the receipt of zakat funds and the charity funds, while the output variables are the use of zakat funds and the charity funds. The results of this study found that 5 BUS have managed social funds efficiently and three other BUS have inefficiency conditions. Furthermore, based on MPI analysis it is found that almost all Islamic Banks has increased productivity by $32.2 \%$ which is supported by $36.4 \%$ increase of TECHCH although EFFCH value decreased by $-2.3 \%$. It indicates that Islamic Banks in Indonesia is already using technology to improve its productivity. Furthermore, from 8 BUS that became the research object, only BRISyariah experienced a decrease in productivity.
\end{abstract}

Keywords: Producitivity, Efficiency, Social Funds, Islamic Banks, Malmquist Productivity Index

\begin{abstract}
Abstrak
Amanah UU No. 21 Tahun 2008 pasal 4 menjelaskan adanya kewajiban bagi perbankan syariah di Indonesia untuk mengelola dana sosial, selain kegiatan penghimpunan dan penyaluran dana. Penelitian ini bertujuan untuk menganalisis tingkat produktivitas dana sosial pada bank syariah. Analisis data menggunakan teknik Malmquist Productivity Index (MPI) pada 8 BUS pada 20132017. Variabel inputnya adalah penerimaan dana zakat dan dana kebajikan, sedangkan variabel outputnya adalah penggunaan dana zakat dan dana kebajikan. Hasil penelitian ini menemukan bahwa 5 BUS telah mengelola dana sosial secara efisien dan 3 BUS lainnya mengalami kondisi inefisiensi. Lebih lanjut, berdasarkan analisis MPI ditemukan bahwa hampir keseluruhan perbankan syariah mengalami kenaikan produktivitas sebesar 32,2\% yang ditopang oleh kenaikan TECHCH sebesar 36,4\% meskipun nilai EFFCH mengalami penurunan sebesar -2,3\%. Hal ini menandakan bahwa perbankan syariah di Indonesia sudah menggunakan teknologi untuk meningkatkan produktivitasnya. Lebih lanjut, dari 8 BUS yang menjadi objek penelitian, hanya BRI Syariah yang mengalami penurunan produktivitas.
\end{abstract}

Kata Kunci: Produktivitas, Efisiensi, Dana Sosial, Bank Syariah, Malmquist Productivity Index

\section{PENDAHULUAN}

Perbankan syariah merupakan sebuah viable alternative untuk mendorong pertumbuhan ekonomi dan mampu menyerap macro-financial shocks karena keuntungan struktural yang dimilikinya dibandingkan perbankan konvensional (Hasan \& Dridi, 2010). Di Indonesia, eksistensi perbankan syariah selama 26 tahun terakhir telah memberikan warna dan variasi tersendiri bagi perkembangan industri perbankan. Perbankan syariah terus mengalami pertumbuhan sejak Pakto 88 dan diikuti dengan beberapa Undangundang yang mendukung perkembangan dan eksistensinya (Pambuko, 2016). OJK (2018) dalam laporannya menjelaskan bahwa 
sampai Maret 2018,jumlah bank syariah di Indonesia sebanyak 13 BUS dengan jumlah kantor sebanyak 1.824 kantor yang tersebar di seluruh Indonesia. Pertumbuhan jumlah BUS ini bisa dikatakan sangat signifikan dimana pada Januari 2010 hanya terdapat 6 BUS dengan 815 kantor. Di sisi lain, pertumbuhan tersebut tidak dibarengi dengan perkembangan pangsa pasar perbankan syariah dimana hingga triwulan I 2018 berada pada posisi $5,74 \%$ dari total aset perbankan nasional. Selain masih di bawah target yang telah ditetapkan, jika dibandingkan dengan pangsa pasar bank konvensional, pangsa pasar bank umum syariah masih sangat rendah, meskipun dalam beberapa tahun terakhir pertumbuhannya lebih tinggi dari perbankan konvensional.

Dalam kondisi ini, analisis produktivitas sangat penting dilakukan karena produktivitas merupakan salah satu bentuk pengukuran kinerja dan dimungkinkan menjadi faktor yang diperhitungkan dalam pengambilan keputusan (Hseu \& Shang, 2005). Salah satunya adalah dalam penggunaan input yang tersedia untuk menghasilkan output yang maksimal sehingga produktivitas digunakan sebagai salah satu indikator utama dalam menilai kemampuan bersaing (Hidayati, 2005). Dengan kata lain, bank syariah yang produktif tentunya akan meningkat daya tawar dan daya saingnya di mata investor dan masyarakat sehingga dapat bertahan dalam ketatnya persaingan di industri perbankan Nasional.

Saat ini literatur tentang produktivitas pada lembaga keuangan telah berkembang cukup pesat dan dikaji oleh banyak peneliti, baik melalui pendekatan parametrik maupun non-parametrik. Dalam konteks perbankan syariah, studi tentang produktivitas umumnya menyimpulkan bahwa produktivitas bank syariah terus mengalami peningkatan (Afiatun \& Wiryono, 2010). Setelah spin off, bank syariah juga semakin meningkat produktivitasnya (Norfitriani, 2016). Hal ini juga berlaku dengan kondisi setelah bank syariah dimerger (Kamarudin, Hue, Sufian, \& Anwar, 2017). Bank syariah (full-fledged) produktivitasnya lebih tinggi daripada unit syariah (office chanelling) (Sufian, 2007). Kemudian, dari sisi kepemilikan, bank syariah asing lebih produktif daripada bank syariah domestik (Kamarudin, Sufian, Loong,
\& Anwar, 2017). Di sisi lain, peneliti lainnya menyebutkan bahwa bank syariah mengalami penurunan produktivitas (Sufian, 2005; Bahrini, 2015; Johnes, Izzeldin, \& Pappas, 2015).

Perlu digarisbawahi, seluruh riset diatas hanya terpaku pada analisis finansial perbankan syariah. Lebih lanjut, peneliti menilai bahwa studi-studi terdahulu telah melewatkan satu aspek penting dari operasional perbankan syariah sebagai salah satu pilar utama pengembangan sistem ekonomi syariah di dunia, yaitu aspek sosial. Hal ini menjadi sangat penting karena lembaga keuangan syariah mempunyai dua peran yang harus berjalan beriringan, yaitu sebagai badan usaha (tamwil) dan badan sosial (maal) sebagaimana diamanahkan oleh UU No. 21 tahun 2008 tentang Perbankan Syariah pasal 4. Dalam pasal tersebut dijelaskan bahwa Bank Syariah dan UUS wajib menjalankan fungsi menghimpun dan menyalurkan dana masyarakat serta dapat menjalankan fungsi sosial dalam bentuk lembaga baitul mal, yaitu menerima dana yang berasal dari zakat, infak, sedekah, hibah, atau dana sosial lainnya dan menyalurkannya kepada organisasi pengelola zakat (RI, 2008).

Maka dari itu, selain evaluasi kinerja yang berkaitan dengan profit, bank syariah juga membutuhkan evaluasi tentang bagaimana institusi menjalankan perannya sebagai badan sosial. Berdasarkan gap research di atas, penelitian ini akan menganalisis tentang kontribusi perbankan syariah dalam menciptakan kesejahteraan masyarakat yang dilakukan dengan menganalisis tingkat produktivitas dalam mengelola dana sosial.

\section{METODE PENELITIAN}

Analisis produktivitas perbankan syariah dalam mengelola dana sosial dilakukan pada 8 BUS di Indonesia, yaitu 1) Bank Muamalat Indonesia, 2) Bank Syariah Mandiri, 3) Bank Mega Syariah, 4) BRI Syariah, 5) BNI Syariah, 6) BCA Syariah, 7) Bank Jabar dan Banten Syariah, dan 8) Bank Victoria Syariah pada periode 2013-2017. Pemilihan sampel dan periode observasi ini didasarkan pada ketersediaan data yang diperoleh dari laporan tahunan perbankan syariah yang telah diaudit melalui teknik dokumentasi. 
Variabel yang digunakan untuk mengukur tingkat produktivitas terdiri dari variabel input dan variabel output. Variabel input terdiri dari penerimaan dana zakat (X1) dan dana kebajikan (X2), sedangkan variabel output terdiri dari penggunaan dana zakat (Y1) dan dana kebajikan (Y2). Sedangkan analisis data dalam penelitian ini menggunakan teknik non-parametrik berupa teknik Malmquist Productivity Index (MPI) yang dikembangkan oleh (Fare, Grosskopf, Norris, \& Zhang, 1994). Pengukuran Malmquist Productivity Index dilakukan dengan alat bantu analisis DEAP (Data Envelopment Analysis Program) 2.1 (Coelli et al., 2005). Metode ini dapat mendekomposisi perubahan produktivitas menjadi perubahan efisiensi teknis dan perubahan teknologi.

Total Factor Productivity (TFP) merupakan perkalian dari indeks perubahan efisiensi, yaitu semua indikasi akan dihitung relatif dengan tahun sebelumnya, sehingga estimasi hasil akan dimulai pada $\mathrm{t}+1$ (Fare et al., 1994). Untuk kriteria Malmquist Index adalah bila nilai malmquist index lebih kecil dari 1 maka terjadi penurunan produktivitas, bila lebih dari 1 maka terjadi peningkatan produktivitas, sedangkan bila sama dengan 1 maka tidak ada perubahan kinerja. Dalam pengukuran produktivitas lembaga keuangan, pendekatan output oriented dinilai lebih tepat digunakan karena berorientasi untuk memaksimalkan output dengan memanfaatkan input-input yang tersedia. Adapun kelebihan metode Indeks Malmquist dibandingkan yang lain adalah tidak memerlukan asumsi perilaku perusahaan (seperti meminimalkan biaya atau memaksimalkan keuntungan). Selain itu, dengan nilai produktivitas yang diperoleh dapat didekomposisi menjadi perubahan efisiensi dan perubahan teknologi. Nilai perubahan produktivitas (TFP) $>1$ menunjukkan peningkatan produktivitas, $\mathrm{TFP}=1$ menunjukkan tidak ada perubahan produktivitas, dan TFP $<1$ menunjukkan terjadinya penurunan produktivitas. Hal tersebut berlaku juga terhadap nilai dekomposisi dimana jika perubahan efisiensi (EC) $>1$ menunjukkan efisiensi yang meningkat, $\mathrm{EC}<1$ menunjukkan efisiensi memburuk, dan perubahan teknologi (TC) $>1$ menunjukkan adanya kemajuan teknologi,
TC $<1$ menunjukkan terjadinya kemunduran teknologi.

Dalam analisis Indeks Malmquist akan digunakan software DEAP yang akan menghasilkan tabel dengan 5 hasil estimasi sebagai berikut: pertama, EFFCH: perubahan efisiensi (relatif dengan perhitungan CRS); kedua, TECHCH: perubahan teknologi; ketiga, PECH: perubahan efisiensi teknis murni (relatif dengan perhitungan VRS); keempat, SECH: perubahan efisiensi skala (effch/ pech); dan kelima, TFPCH: perubahan (faktor) produktivitas total.

\section{HASIL DAN PEMBAHASAN}

\section{Analisis Efisiensi Pengelolaan Dana Sosial oleh Perbankan Syariah di Indonesia}

Analisis efisiensi pada 40 DMU (Decision Making Unit) berorientasi output (output orientated) dengan menggunakan asumsi VRS (Variable Return to Scale). Asumsi VRS memungkinkan adanya konklusi bahwa penambahan 1 unit input tidak harus menghasilkan tambahan sebesar 1 unit output yang lebih besar atau lebih kecil dari 1. Hasil perhitungan efisiensi pengelolaan dana sosial pada 8 BUS melalui pendekatan Data Envelopment Analysis (DEA) pada periode 20132017 disajikan pada tabel 1 berikut.

Tabel 1. Tingkat Efisiensi 8 BUS Periode 2013-2017

\begin{tabular}{lccccc}
\hline \multicolumn{1}{c}{ Bank } & $\mathbf{2 0 1 3}$ & $\mathbf{2 0 1 4}$ & $\mathbf{2 0 1 5}$ & $\mathbf{2 0 1 6}$ & $\mathbf{2 0 1 7}$ \\
\hline Muamalat & 1 & 1 & 1 & 1 & 1 \\
Syariah Mandiri & 1 & 1 & 1 & 1 & 1 \\
Mega Syariah & 1 & 1 & 1 & 1 & 1 \\
BRI Syariah & 1 & 1 & 1 & 1 & 1 \\
BNI Syariah & 1 & 1 & 1 & 0.931 & 1 \\
BCA Syariah & 1 & 1 & 1 & 1 & 1 \\
BJB Syariah & 1 & 1 & 0.156 & 1 & 1 \\
Victoria Syariah & 1 & 1 & 1 & 1 & 0.846 \\
\hline \multicolumn{1}{c}{ Mean } & $\mathbf{1}$ & $\mathbf{1}$ & $\mathbf{0 . 8 9 5}$ & $\mathbf{0 . 9 9 1}$ & $\mathbf{0 . 9 8 1}$ \\
\hline
\end{tabular}

Berdasarkan hasil perhitungan efisiensi dana sosial pada delapan Bank Umum Syariah (BUS) di Indonesia dalam kurun waktu 2013 - 2017 diketahui bahwa bank syariah hanya mampu mencapai kondisi efisien pada 2 tahun pertama, yaitu tahun 2013 dan 2014. Adapun 
Tabel 2. Tingkat Produktivitas 8 BUS

Periode 2013-2017

\begin{tabular}{lccccc}
\hline \multicolumn{1}{c}{ BUS } & EFFCH & TECHCH & PECH & SECH & TFPCH \\
\hline Bank Syariah & & & & & \\
Muamalat & 0.968 & 1.409 & 1.000 & 0.968 & 1.365 \\
Syariah Mandiri & 0.773 & 1.596 & 1.000 & 0.773 & 1.233 \\
Mega Syariah & 1.000 & 1.216 & 1.000 & 1.000 & 1.216 \\
BRI Syariah & 0.887 & 1.086 & 1.000 & 0.887 & 0.963 \\
BNI Syariah & 1.010 & 1.063 & 1.000 & 1.010 & 1.074 \\
BCA Syariah & 0.723 & 1.698 & 1.000 & 0.723 & 1.228 \\
BJB Syariah & 2.335 & 1.364 & 1.000 & 2.335 & 3.186 \\
Victoria Syariah & 0.733 & 1.639 & 0.959 & 0.764 & 1.201 \\
\hline \multicolumn{1}{c}{ Mean } & $\mathbf{0 . 9 7 7}$ & $\mathbf{1 . 3 6 4}$ & $\mathbf{0 . 9 9 5}$ & $\mathbf{0 . 9 8 2}$ & $\mathbf{1 . 3 3 2}$ \\
\hline Tahun Observasi & & & & & \\
2013 - 2014 & 1.421 & 2.190 & 1.000 & 1.421 & 3.113 \\
2014 - 2015 & 0.824 & 0.565 & 0.793 & 1.039 & 0.465 \\
2015 - 2016 & 1.232 & 1.649 & 1.250 & 0.986 & 2.032 \\
2016 - 2017 & 0.631 & 1.697 & 0.988 & 0.639 & 1.072 \\
\hline \multicolumn{1}{c}{ Mean } & $\mathbf{0 . 9 7 7}$ & $\mathbf{1 . 3 6 4}$ & $\mathbf{0 . 9 9 5}$ & $\mathbf{0 . 9 8 2}$ & $\mathbf{1 . 3 3 2}$ \\
\hline
\end{tabular}

tiga tahun setelahnya tidak mampu mencapai kondisi efisien yang dapat dilihat dari nilai efisiensi < $1(100 \%)$. Hal ini menunjukkan bahwa pada tahun 2015 - 2017 bank syariah mengalami misalokasi sumber daya sehingga terjadi kondisi inefisiensi dalam mengelola dana sosial yang berupa dana zakat dan dana kebajikan.

Menariknya, selama periode observasi, hanya ada 3 DMU yang mengalami inefisiensi dan tersebar di 3 periode yang berbeda. Pada tahun 2015, bank syariah yang mengalami inefisiensi adalah Bank Jabar Banten Syariah dengan nilai sebesar 0,156 (15,6\%), pada tahun 2016, bank syariah yang mengalami inefisiensi adalah BNI Syariah dengan nilai sebesar 0,931 (93,1\%) dan tahun 2017, bank syariah yang mengalami inefisiensi adalah Bank Victoria Syariah dengan nilai sebesar 0,846 $(\mathbf{8 4}, \mathbf{6} \%)$. Hasil analisis potencial improvement memberikan informasi yang identik dimana kondisi inefisiensi tersebut disebabkan oleh ketidakmampuan ketiga DMU untuk mengalokasikan sumber daya yang dimiliki. Dengan kata lain, untuk mencapai kondisi efisien, 3 DMU yang mengalami inefisiensi harus menambahkan jumlah penyaluran dana zakat dan dana kebajikan kepada masyarakat, bagi secara langsung atau melalui lembaga pengelola zakat yang ditunjukkan oleh perbankan syariah. Selain 3 bank syariah di atas, 5 perbankan syariah lainnya telah mencapai kondisi efisien.

\section{Analisis Produktivitas Pengelolaan Dana Sosial oleh Perbankan Syariah di Indonesia}

Analisis produktivitas pada 40 DMU (Decision Making Unit) juga berorientasi output (output orientated) dengan menggunakan asumsi VRS (Variable Return to Scale). Berbeda dengan analisis efisiensi yang menggunakan pendekatan Data Envelopment Analysis (DEA), analisis produktivitas ini menggunakan pendekatan Malmquist Productivity Index (MPI). Pada analisis produktivitas, nilai 1 artinya tidak ada perubahan produktivitas, $x>1$ artinya ada peningkatan produktivitas, dan $x<1$ artinya ada penurunan produktivitas. Hasil perhitungan produktivitas pengelolaan dana sosial oleh 8 BUS pada periode 2013-2017 disajikan pada tabel 2.

Produktivitas pengelolaan dana sosial pada 8 BUS sepanjang periode observasi peningkatan produktivitas sebesar 33,2\% $(1,332)$. peningkatan produktivitas ini ditopang oleh peningkatan nilai rata-rata technological changes (TECHCH) dengan nilai sebesar $36,4 \%(1,364)$. Namun disisi lain efficiency change (EFFCH) mengalami penurunan produktivitas sebesar $-2,3 \%(0,977)$. Penurunan tingkat efisiensi ini disebabkan sebabkan oleh penurunan dua komponen pembentuk EFFCH, 


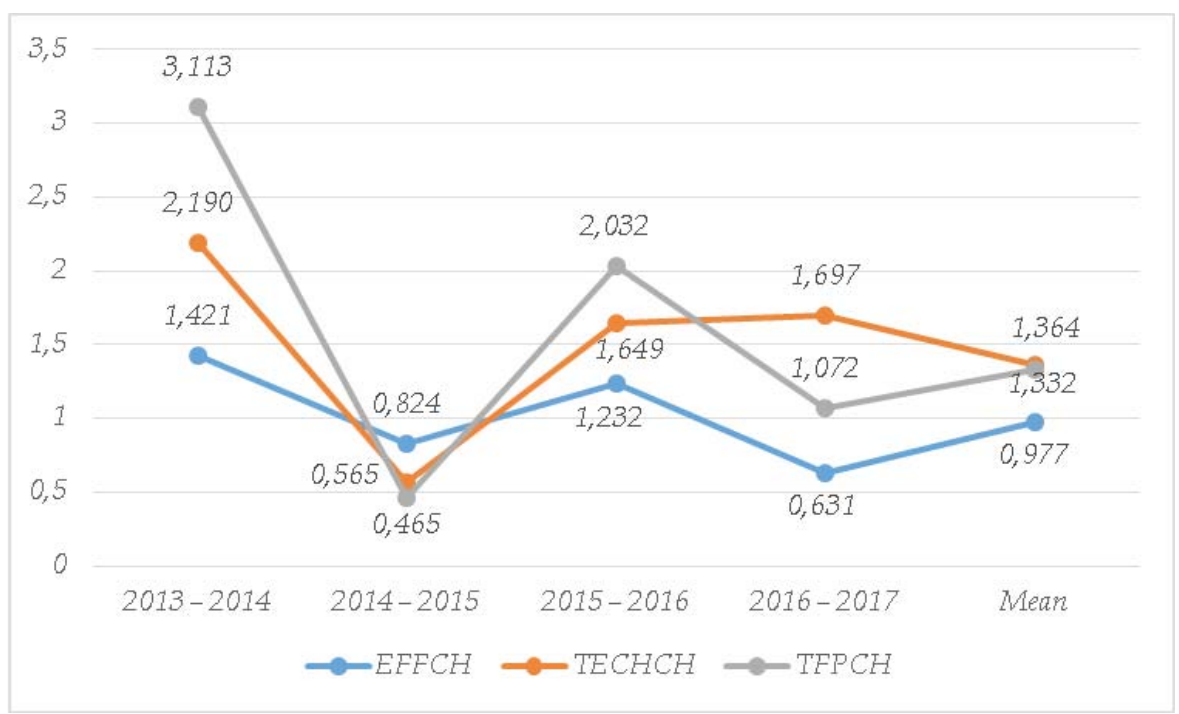

Gambar 1. Perubahan Tingkat Produktivitas Perbankan Syariah 2013 - 2017

yaitu penurunan nilai Pure Efficiency Change $(\mathrm{PECH})$ atau aspek manajerial sebesar $-0,5 \%$ $(0,995)$ dan penurunan nilai Scale efficiency Change (SECH) sebesar $-1,8 \%(0,982)$.

Lebih lanjut, analisis yang dilakukan pada individual banking diperoleh hasil bahwa 7 BUS mengalami peningkatan produktivitas dan 1 BUS (BRI Syariah) yang mengalami penurunan produktivitas sebesar $-3,7 \%(0,963)$. BUS yang mengalami kenaikan produktivitas dalam mengelola dana sosial, yaitu: Bank Muamalat (36,5\%), Bank Mandiri Syari'ah (23,3\%), Bank Mega Syari'ah (21,6\%), Bank BNI Syari'ah $(7,4 \%)$, Bank BCA Syari'ah $(22,8 \%)$, Bank BJB Syari'ah (218,6\%), dan Bank Victoria Syari'ah sebesar $(20,1 \%)$. BUS yang mengalami peningkatan produktivitas tertinggi adalah Bank BJB Syari'ah (218.6\%) dan BUS yang mengalami peningkatan produktivitas terendah adalah Bank BNI Syari'ah (7,4\%).

Tingginya nilai TFPCH Bank BJB Syariah dipengaruhi oleh tingginya nilai efisiensinya, yaitu sebesar 133,5\% (2,335). Hal ini dikarenakan oleh peningkatan aspek manajerial $(\mathrm{SECH})$ yang memiliki nilai sebesar 2,335 (133,5\%) dan ditopang oleh stabilnya nilai PECH sebesar 1,000. Lain daripada itu, faktor perubahan teknologi juga mendukung peningkatan produktivitas ini dengan nilai sebesar 1,364 $(36,4 \%)$ sehingga mampu menopang nilai TFPCH yang tinggi sepanjang tahun 2013 2017.Senada dengan BJB Syariah, terdapat 2
BUS yang meningkat produktivitasnya dengan didukung oleh perubahan teknologi dan pencapaian kondisi efisien, yaitu Bank Mega Syariah dan BNI Syariah.

Kemudian, 4 BUS lainnya yang juga mengalami peningkatan produktivitas selama periode observasi hanya ditopang oleh perubahan teknologi, sedangkan level efisiensinya mengalami penurunan. Keempat BUS tersebut adalah Bank Muamalat, Bank Syariah Mandiri, BCA Syariah, dan Bank Victoria Syariah. Hal ini dapat dilihat dari nilai TECHCH $>1$ dan nilai EFFCH $<1$. Di sisi lain, BRI Syariah yang mengalami penurunan produktivitas sebesar 3,7\%, diakibatkan oleh penurunan nilai EFFCH sebesar -11,3\% $(0,887)$ meskipun ada peningkatan aspek teknologi (TECHCH) sebesar 8,6\%. Menurunnya EFFCH diakibatkan oleh menurunnya efisiensi skala (SECH) sebesar $-11,3 \%(0,887)$, sedangkan efisiensi manajerial telah efisien $(1,000)$.

Bagan 1 di bawah ini merupakan grafik perubahan nilai produktivitas perbankan syariah dalam mengelola dana sosial dan komponen yang mempengaruhinya, yaitu tingkat efisiensi dan perubahan teknologi selama periode observasi. Dalam lima tahun terakhir, terjadi fluktuasi level produktivitas dimana pada tahun 2014-2015 yang mengalami penurunan produktivitas sebesar $-53,5 \%$ yang juga disebabkan oleh penurunan nilai efisiensi (EFFCH) dan perubahan teknologi 
(TECHCH). Nilai EFFCH pada tahun 20142015 sebesar 0,824 (-17,6\%) dan nilai TECHCH sebesar 0,565 (-43,5\%). Namun di dua tahun selanjutnya, produktivitas perbankan syariah dalam mengelola dana sosial terus mengalami peningkatan, masing-masing sebesar 103,2\% (2,032) dan 7,2\% (1,072). Secara garis besar, peningkatan atau penurunan tingkat produktivitas perbankan syariah dipengaruhi oleh perubahan tingkat efisiensi, sedangkan perubahan teknologi menjadi variabel kontrol yang menopang pencapaian tingkat produktivitas.

\section{KESIMPULAN}

Hasil analisis menggunakan teknik Data Envelopment Analysis (DEA) menemukan bahwa 5 BUS telah mengelola dana sosial secara efisien dan 3 BUS lainnya mengalami kondisi inefisiensi. Bank syariah yang telah beroperasi secara efisien adalah Bank Muamalat, Bank Syariah Mandiri, Bank Mega Syariah, BRI Syariah, dan BCA Syariah. Adapun ditinjau dari periode observasi, hanya pada tahun 2013 dan 2014 bank syariah mampu mengelola dana sosial secara efisien. Kemudian berdasarkan analisis Malmquist Productivity Index (MPI) disimpulkan bahwa hampir keseluruhan perbankan syariah mengalami kenaikan produktivitas dengan presentase rata-rata Total Factor Productivity Change (TFPCH) adalah 32,2\% meskipun nilai Efficiency Change (EFFCH) mengalami penurunan sebesar $-2,3 \%$ dan ditopang oleh kenaikan Technological Change (TECHCH) sebesar 36,4\%. Hal ini menandakan bahwa perbankan syariah di Indonesia sudah menggunakan teknologi untuk meningkatkan produktivitasnya. Lain daripada itu, dari 8 BUS yang menjadi objek penelitian, hanya BRI Syariah yang mengalami penurunan produktivitas.

Sebagai rekomendasi, riset tentang analisis efisiensi dan produktivitas perbankan syariah dalam mengelola dana sosial masih perlu dilakukan karena belum ada riset sejenis. Adapun merujuk pada temuan ini, untuk mencapai level produktivitas tertentu, perbankan syariah perlu terlebih dahulu mencapai kondisi efisien dan ditopang dengan perubahan teknologi yang positif.

\section{UCAPAN TERIMA KASIH}

Artikel ini merupakan luaran dari kegiatan PKM-PSH (Program Kreativitas Mahasiswa-Penelitian Sosial Humaniora) yang dibiayai oleh Dirjen Belmawa - Ristekdikti. Kami mengucapkan terima kasih kepada Dirjen Belmawa - Ristekdikti atas pembiayaannya sehingga artikel ini dapat dipublikasikan dan kepada Universitas Muhammadiyah Magelang atas segala fasilitas dan dukungan dalam menyelesaikan kegiatan PKM-PSH ini.

\section{DAFTAR PUSTAKA}

Afiatun, P., \& Wiryono, S. K. (2010). Efficiency and Productivity of Indonesian Islamic Banking. Jurnal Manajemen Teknologi, 9(3), 264-278.

Bahrini, R. (2015). Productivity of MENA Islamic banks: a bootstrapped Malmquist index approach. International Journal of Islamic and Middle Eastern Finance and Management, 8(4). https://doi. org/http:/ / dx.doi.org/10.1108/ IMEFM-11-2014-0114

Coelli, T., Rao, P. D. S., O’Donnell, C. J., \& Battese, G. E. (2005). An Introduction to Efficiency and Productivity Analysis. Springer US. https://doi.org/10.1007/ b136381

Fare, R., Grosskopf, S., Norris, M., \& Zhang, Z. (1994). Productivity growth, technical progress and efficiency change in Industrialised Countries. The American Economic Review, 84(1), 66-83. https:// doi. org/10.1111/j.1467-8268.2004.00089.x

Hasan, M., \& Dridi, J. (2010). The Effects of the Global Crisis on Islamic and Conventional Banks: A Comparative Study. IMF Working Paper (Vol. 02). https:/ / doi.org/10.1142/ S1793993311000270

Hidayati, J. (2005). Analisis kinerja bank dengan DEA. Jurnal Sistem Teknik Industri, 6(2), 17-23.

Hseu, J. S., \& Shang, J. K. (2005). Productivity changes of pulp and paper industry in OECD countries, 1991-2000: A nonparametric Malmquist approach. Forest Policy and Economics, 7(3), 411-422. https:// doi.org/10.1016/j. forpol.2003.07.002 
Johnes, J., Izzeldin, M., \& Pappas, V. (2015). Efficiency and productivity change in Islamic and conventional banks: Evidence from the Gulf Cooperation Council (GCC) countries. In 13th International Conference on Data Envelopment Analysis. Braunschweig: University of Huddersfield. Retrieved from http:/ / eprints.hud.ac.uk/27824/

Kamarudin, F., Hue, C. Z., Sufian, F., \& Anwar, N. A. M. (2017). Does productivity of Islamic banks endure progress or regress?: Empirical evidence using data envelopment analysis based Malmquist Productivity Index. Humanomics, 33(1), 84-118. https:// doi.org/http://dx.doi. org/10.1108/H-08-2016-0059

Kamarudin, F., Sufian, F., Loong, F. W., \& Anwar, N. A. M. (2017). Assessing the Domestic and Foreign Islamic Banks Efficiency: Insights from Selected Southeast Asian countries. Future Business Journal, 3(1), 33-46. https:// doi.org/10.1016/j.fbj.2017.01.005

Norfitriani, S. (2016). Analisis efisiensi dan produktivitas bank syariah di Indonesia sebelum dan sesudah Spin Off. Jurnal
Ekonomi Syariah Indonesia, 6(2), 134-143. Retrieved from http:// ejournal.almaata.ac.id/index.php/JESI/ article/view/430

OJK. (2018). Statistik Perbankan Syariah - Maret 2018. Jakarta.

Pambuko, Z. B. (2016). Determinan Tingkat Efisiensi Perbankan Syariah di Indonesia : Two Stages Data Envelopment Analysis. Cakrawala: Jurnal Studi Islam, 11(2), 178-194.

RI. Undang-undang Nomor 21 Tahun 2008 Tentang Perbankan Syariah (2008). Indonesia: Pemerintah Republik Indonesia.

Sufian, F. (2005). Sources of Productivity Changes of Commercial Banks in Developing Economy: Evidence from Malaysia, 1998-2003. International Journal of Applied Econometrics and Quantitative Studies, 2(3), 87-100.

Sufian, F. (2007). Malmquist Indices of productivity Change in Malaysian Islamic Banking Industry: Foreign Versus Domestic Banks. Journal of Economic Cooperation, 28(1), 115-150. https:/ / doi. org/10.1007/BF02294970 